\title{
COVID-19 Pandemic and MSMEs: Impact and Mitigation
}

\author{
David R. Tairas ${ }^{\mathrm{a}, *}$ \\ ${ }^{a}$ School of Strategic and Global Studies, Universitas Indonesia
}

\begin{abstract}
Indonesia announced the first COVID-19 case in early of March 2020. Since then, the mobility restriction has hampered the economy, including the micro, small and medium enterprises (MSMEs) businesses. This study aims to explore the types of challenges encountered by MSMEs to sustain their businesses during the hardship. Descriptive qualitative method is used, with data sourced from interview with 34 MSMEs, one in each province in Indonesia, as well as secondary sources including research journals and various reports on the COVID-19 pandemic. The results show that business owners experience difficulties in producing goods and services because of the raw materials shortage, financial liquidity and decreasing demand. Policy and managerial implications of the study are provided.
\end{abstract}

Keywords: impact; pandemic; COVID-19; mitigation; MSMEs

JEL Classification: D90; F61; L32

${ }^{*}$ Corresponding Address: Gedung SKSG/SIL J1. Salemba Raya 4, Jakarta Pusat 10430. Email: davidronaldtairas@yahoo.com. 


\section{Introduction}

The coronavirus disease (COVID-19) pandemic has hit many countries around the globe and put a halt into humanities' activities. Government of every nation has sanctioned policies from harsh, fast-acting disease proliferation prevention to lenient, often ill-conceived to protect its citizen and its economy. Since the WHO has declared the COVID-19 as a pandemic in 30th January (WHO, 2020), many countries decided to enact lockdown and banning any social gatherings and business activities. The lockdown jeopardizes economic growth with the hope of flattening the pandemic curve, ergo successfully dispelling the virus without losing too many civilian lives and continuing business activities. Some countries have been successful in dispelling the virus cases within their territory and eases the lockdown such as Vietnam and Cuba, whilst others such as Italy and USA had difficulties in containing the pandemic, resulting in even more new cases and deaths.

The global impact of COVID-19 is profound and represents the most serious public health threat since the influenza pandemic of 1918 (Vranckx et al., 2020). COVID-19 outbreak that has disrupted various activities creates an increased risk to the global economy. The early year optimism that the world economy could grow to $3.3 \%$ in 2020 will almost certainly not be achieved. Some large companies reduce business activities significantly and supply to several large industries is hampered. Many MSMEs with short-term business contracts are under pressure (Fernandes, 2020).

The outbreak of COVID-19 in January 2020 began in Wuhan, China, and spread across the world. On March 11, WHO announced COVID-19 as a pandemic, which led to significant economic shutdowns around the world in an effort to contain the virus. In addition to the loss of life, the pandemic has also severely interrupted trade and supply chains, which in turn has had a significant effect on the Chinese economy (McCloskey \& Heymann, 2020). In China, many enterprises had to shut down for more than a month. However, after permission was given to reopen, many micro, small and medium-sized enterprises (MSMEs) have found it difficult to resume operation, which has resulted in further significant economic losses and put many in danger of closing permanently (Lu et al., 2020).

China will become a global concern because of its position as the secondlargest economy in the world. The size of the country's economy has reached US\$13.6 trillion, contributing 17\% of world's Gross Domestic Product (GDP) (Wang et al., 2019). China is the world's largest exporter of intermediate goods. Some experts estimate the coronavirus outbreak will have a greater economic impact than the SARS outbreak. The reason is that the Chinese economy is currently in a moderation trend and the Chinese economy is more integrated with the global economy, hence what happens in China will be felt by other countries.

The situation is not so far off in Indonesia, as the pandemic has reached major 
cities and even rural communities across the archipelago. With the spread not being contained in a proper fashion by the government, numbers of people tested positive keeps on rising with no clues on when it will cease. Recent policies enacted by the government is the implementation of large-scale social distancing (PSBB) that works by preventing any gatherings and prohibiting offline commercial activities. This policy has caused business entities, especially MSMEs, suffered revenue loss and a large number of them went out of business, having reduced order and difficulties in maintaining profitability.

A study conducted by the Association of Business Development Services Indonesia (ABDSI, 2020) reported that from 6,405 surveyed MSMEs, 48.3\% reported difficulty in securing supply line, $92.6 \%$ in need of debt restructuring, and $26.6 \%$ are facing cash flow problems thus unable to pay-off the debt (SimpulRakyat.co.id, 2020). Moreover, a report by ILO suggests that, from 571 businesses as their sample, $68 \%$ reported a disruption of their business activity due to the pandemic, $65 \%$ put a halt on their operation and $3 \%$ had permanently stopped operating. In addition, roughly $80 \%$ reported a sharp decline in revenue; $34 \%$ reported had lost a quarter of their revenue, $18 \%$ had lost $25-50 \%$ of their revenue, and $28 \%$ had lost over half of their revenue. It is speculated that throughout 2020 businesses will suffer more revenue slump due to the pandemic (ILO, 2020). Revindo et al. (2020) suggested that MSMEs in tourism destinations suffered the most from the pandemic as their sales rely solely on tourist visits, which have been down to nearly zero since March.

Baldwin and di Mauro (2020) highlights the multi-faceted nature of the Coronavirus crisis, in that the current crisis hits both the supply-side and least of all, the demand-side as well. In light of the recent implementation of PSBB, businesses have experienced a slump in revenue, and may have no choice but to cut corners - of which a crucial aspect is the labor cost. Statistics Indonesia predicts that, with assumption COVID-19 ending in late May 2020, the 2020 unemployment rate may well reach $4.8-5 \%$ of the year's total labour force. By 20th April 2020, the Ministry of Manpower suggests that the number of workers that have been laid off amount to 2.1 million people. One of the direct consequences of such massive lay-off is an increase in the number of people falling below the poverty line. A study by Suryahadi et al. (2020) shows that the poverty rate would increase from the previous rate of $9.2 \%$ in September 2019 to $9.7 \%$ in late 2020, implying an increase of 1.3 million people will fall below the poverty line.

This study aims to investigate the types of challenges encountered by MSMEs during the COVID-19 pandemic and to formulate the appropriate policy measures that can mitigate the impact of the pandemic on MSMEs.

\section{Methodology}

This research uses a descriptive qualitative method that focuses on supporting documents or articles in drawing conclusions. According to Miles and Huberman in Creswell (2009), the descriptive qualitative research can be interpreted 
as an investigative process in which the author slowly deciphers a social phenomenon by distinguishing, comparing, duplicating, cataloguing, and classifying research objects. According to Stake (in Denzin \& Lincoln, 1994), case studies do not always use a qualitative approach as there are several case studies that use quantitative approach. In discussing case studies, the researcher can emphasize a qualitative, naturalistic approach, based on cultural and phenomenological interests. In addition, in qualitative research methods the researcher makes a detailed description by describing something that is seen and providing interpretation according to the author's point of view, as well as from the perspective contained in the literature (Creswell, 2009).

Qualitative research is inductive in nature, as it does not start from deduction of theory. Rather, it starts from the field, namely empirical facts. Researchers go into the field, learn a process of discovery that occurs naturally, record, analyze, interpret and report and draw conclusions from the process. The basis of qualitative research is constructivism which assumes that reality is plural, interactive and exchange of social experiences interpreted by each individual. Qualitative researchers believe that truth is dynamic and can be found only through the examination of people through their interaction with their social situation (Danim, 2002).

In qualitative research, data collection involves interactions between researchers and data sources. Both researchers and data sources may have different backgrounds, views, beliefs, values, interests and perceptions, hence the data collection, analysis, and report generation will be bound by their respective values. The final results of qualitative research not only produce data or information that is difficult to find through quantitative methods, but must also be able to produce meaningful information or new hypotheses and knowledge that can be used to help overcome problems and improve the standard of human life (Bogdan \& Biklen, 2007).

This study uses two types of data; primary and secondary. The secondary data sources from websites of the statistical and news centre agency, as well as the literature study including books, scientific journals, institutional documents, official articles from non-governmental organizations' websites, media, and other relevant sources. Primary data collection was carried out in the field interviews. The respondents were MSMEs with a total sample of 34 MSMEs, one in each province (see Table 1). The interviews were carried out through telephone and the results of the interviews were recorded. The main questions of the interview included: firm characteristics, owners' characteristics, location characteristics, sectors/products, challenged encountered during the COVID-19 pandemic, efforts and innovation to survive the pandemic, and the funding or assistance received from the government. The interviews were conducted in Bahasa Indonesia and then translated to English to be presented in this paper. There is a various def- 
inition of MSMEs in Indonesia. ${ }^{1}$ In this study, a business falls to the MSMEs category if it has less than 100 employees, assets values of maximum ten billion Rupiahs, or turnovers of maximum 50 billion Rupiahs.

\section{Results}

\subsection{Impact and Mitigation in Various Countries}

Advancement in connectivity and digitization enables vertically and horizontally integrated networks ${ }^{2}$. A currently technical and dynamic business environment where various types of relationships exist requires high-level collaboration and transparency between stakeholders. Hence, it is important that businesses, especially MSMEs develop and enhance their relational capabilities (Els et al., 2020). ${ }^{3}$

Even before the COVID-19 outbreak, Nelson (2020) argued that MSMEs are challenged by the lack of entrepreneurial training by local governments, uncertain demand for their products, lack of experience, skills and knowledge, limited access to finance, poor marketing skills, poor managerial, and lack of planning. Further, MSMEs also have poor management in deciding the core strategies and business preferences, poor management of the procurement system, improper integration of the central supplier database, and dealing with the impact of e-procurement system implemented by the local governments.

However, the COVID-19 outbreak has had an alarming effect on human life and economies. The global manufacturing experiences extended plant closure periods, which stagnates the production activities (Yu \& Aviso, 2020). ${ }^{4}$ The importance of resilience, accuracy of strategy, and entrepreneurship in the context of the struggle against the pandemic has been shown in the cases of China, South Korea, and Singapore, with enormous support from the government to both the business and the society (Liu et al., 2020). ${ }^{5}$

According to Karnon (2020), the COVID-19 crisis is a waiting game for the economy as it cannot begin to recover until the pandemic is fully controlled and social distance practices and regulations are lifted. This waiting period requires appropriate policies and actions to reduce the impact of the crisis on

\footnotetext{
${ }^{1}$ See Revindo (2017) for different definitions of MSMEs used by various institutions and agencies in Indonesia.

${ }^{2}$ According to Els et al. (2020), the progress in connectivity and digitalization enables MSMEs to be vertically integrated network of relationships with government and horizontal relationships with customers and partners.

${ }^{3}$ According to Els et al. (2020), research environment, partners, consumers and government play an important role in the sustainability of MSMEs' businesses.

${ }^{4} \mathrm{Yu}$ and Aviso (2020) reported the temporary closure of the manufacturing, resulting in the termination of employment and the obstruction of production.

${ }^{5}$ This study shows the need for government intervention in dealing with Covid-19 pandemic for the MSMEs to survive the hardships.
} 
government budget deficits, deteriorating social life and people's health and increasing inequality, but may also provide opportunities for the governments to reduce social divisions which have been increasing in various countries in recent years.

According to Gumbi and Twinomurinzi (2020) the smart manufacturing, Industry 4.0 and smart factory are strategies considered as major needs for MSMEs to overcome the challenges caused by the pandemic. Further, Goldberg et al. (2020) suggests six main strategies for domestically-oriented MSMEs to manage the negative impact of the pandemic. The first mitigation is to monitor customer behaviour. MSMEs may need to change their activities to match changes in customer behaviour. For example, MSMEs in the service industries are at risk because of travel restrictions and customer fears of virus contamination, making it more difficult to cover cash flow losses. Secondly, MSMEs owners must manage their cash flow such that it can survive under an extended pandemic scenario, without which MSMEs will run the risk of working capital shortage, labour and material shortages, and lower customer demand that in turn can reduce company's turnover. Thirdly, MSMEs owners must communicate their problems with suppliers. The need for communication with suppliers is to avoid raw material shortages and to ensure the production process can still run.

Fourth, MSMEs must find the balance between the supply and demand of their products. They should carefully consider whether production can be increased or reduced to maintain the scarce imported inventories. Fifth, MSMEs owners must consider a work from home policy. MSMEs should build internal systems and processes that allow employees to work from home. This can help MSMEs maintain productivity and greatly reduce the possibility of employees contracting the virus. However, long-distance work can be applicable for MSMEs in professional services, but is less applicable for MSMEs in the manufacturing, retail and restaurant sectors. Lastly, MSMEs must brace for late payment collections. If a business is a part of a large supply chain, it may face late payments from customers who have decreased sales as a result of the pandemic. ${ }^{6}$

With regard to the cash flow management during the crisis, Van Tiem and Burns (2020) perfectly states "At this time of uncertainty, it is important that business owners take immediate steps to ensure they have the necessary cash flow reserves for the coming months. Ironically, the best time to apply for finance is when it is least needed when the business is booming. This happens when lenders are more likely to approve credit facilities which are then available to business owners for this type of unplanned crisis. Of course, if you haven't gotten the money needed to bridge through this difficult time, then the next best time to apply for finance is now before reaching the cash cliff."

Although discussions about the implications of the COVID-19 pandemic on business are just beginning to emerge, the pandemic should be analyzed from bigger perspective. Any effort to mitigate the impact of the pandemic to MSMEs

\footnotetext{
${ }^{6}$ Goldberg et al. reported the importance of these six strategies for MSMEs in dealing with the pandemic in Durban, South Africa.
} 
should also consider the impact on societal problems that in turn affects businesses, hence for a policy response to be effective, it should address the economic consequences as well as social impact. On the base of this approach, it has been suggested that business entities to be more deeply involved in alleviating the crisis, as there are different effects the crisis has on individuals and societies and different abilities to deal with the crisis. It is therefore imperative for businesses to take this crisis as a moment to reflect on the consequences of their business practices on societal inequality, and redesign their organizations to create more equal societies (Li et al., 2020).

Grint (2020) argued that if the society is imposed by the wrong decision for the problem that they are facing now then they are likely worse-off. Hence, the decision about required responses and and the seek for collective ideas when the virus is already spread requires leadership quality. Kanupriya (2020) underlines that "A number of solutions have been offered for an effective tackling of this deadly disease, keeping in mind the global developments. All in all, the crisis must serve as an important experience for the entire civilization and imparts lessons in health, social, political and economic spheres." The fight against the coronavirus infection should be an emergency affair, which can only be overcome by active cooperation of different trades and professions, such as medical industry, transportation, logistics, government administration and technology manufacturers ( $\mathrm{Xu}$ et al., 2020).

Finally, it is pivotal to understand the relationship between stress and engagement given the large changes that have occurred across public sector organizations due to public sector reforms and recent cutback management strategies (Breaugh, 2020). Hence, it is important to consider the real economic impact related to lost workdays due to quarantine and social isolation as well as travel restrictions that may negatively impact the access to care and ability to pay for care.

Countries who are successful at aggressive screening, early identification, patient isolation, contact tracing, quarantine, and infection control methods should also address the risk of stigmatization among populations and the negative effects which could occur. Efforts geared towards general education about the disease and the rationale for quarantine and public health information provided to the general public is crucial in this regard. The cases of COVID-19 pandemic will continue to rise and the virus will remain for future infections. Timely and appropriate public health interventions addressing cultural impact and risk for stigmatization along with proper screening, treatment, and follow up for affected individuals and close contacts can reduce the number of infections, serious illness, and deaths (Bick, 2020).

\subsection{The Case of Indonesia}

It remains to be seen whether MSMEs in Indonesia can survive the COVID19 pandemic period and whether the government can mitigate its impact on 
MSMEs. The pandemic has affected the country's overall economy, as voiced by large business throughout the country. At present the most affected and most vulnerable MSMEs due to the pandemic are those in food and beverage sector and other business sectors that rely on people activities and mobility (ABDSI, 2020). A large number of MSMEs have no choices but to foreclose their business after the virus outbreak mainly because they lost the market due to the weakening of people's purchasing power. This has been evident due to the decline in economic activity as a consequence of large-scale social restrictions in a number of regions. However, many MSMEs who still have demand for their products encounter other challenges, namely the difficulties in obtaining the raw materials (ABDSI, 2020).

In an interview with the owner of a culinary business 'Enterprise 12', it was revealed that the firm had to stop the production activities after the virus outbreak. This is done in order to maintain the safety of employees, business partners, and also production in accordance with government policy. The owner further explained: "Actually, there is no problem to obtain the raw materials, but to continue producing we have to go back and forth to the bottle suppliers and then pass them through to the market. If this is done, there is a great risk of contracting COVID-19 transmission to me or to other parties.".

Another problem was conveyed by the owner of 'Enterprise 11' culinary product in Jakarta. At present the sales of the business have experienced a very significant decline, worsened by the increase in raw material price. The owner further explained "Since the pandemic began, my business has been severely affected. Usually within a day, the orders through GoFood and Grab Food is quite busy, but now it is very few. Actually, it happens several times that there is no single order in a whole day. It also happens to our resellers, which only received a much fewer order than usual.".

Meanwhile, the owner of a culinary MSME culinary under the name 'Enterprise 27' from Makassar was forced to reduce its production because the price of onions and cashews became very expensive. In addition, the decline in turnover was also down to $50 \%$. The owner further added "Because the price of raw materials is increasingly expensive, a slight decrease in production causes the profit to decrease dramatically than usual. To overcome this, I now use sales promotions by offering discounts and online media.".

There were 34 interviewed MSMEs, one in each province (see Table 1). Overall, there are five main constraints encountered by MSMEs to sustain their businesses, namely finance, raw materials, labour, marketing, and attractive packaging. The types of constraints vary across MSMEs' sectors and regions.

Figure 1 summarizes the main challenges encountered by the MSMEs during the pandemic. It shows that 'finance' constitute $25 \%$ of the major challenges, which implies that funding or financial access is needed by MSMEs to survive the hardship. The second main challenge is the availability and affordability of raw materials, constituting $21 \%$ of all challenges. Raw materials are still the decisive factor in MSMEs' business continuity since it influences the quality of the products. The third main challenge is the labor as the MSMEs generally 
Table 1: Results of Interviews with MSMEs

\begin{tabular}{|c|c|c|c|c|}
\hline No & $\begin{array}{l}\text { Name of the } \\
\text { Firms }\end{array}$ & Province & $\begin{array}{l}\text { Constraints in Business During } \\
\text { Pandemic }\end{array}$ & Business Fields \\
\hline 1 & Enterprise 1 & Aceh & Finance, Raw Materials & Restaurant \\
\hline 2 & Enterprise 2 & North Sumatra & Finance, Raw Materials & Restaurant \\
\hline 3 & Enterprise 3 & West Sumatra & $\begin{array}{l}\text { Finance, Raw Materials, Mar- } \\
\text { keting }\end{array}$ & Tailor \\
\hline 4 & Enterprise 4 & Riau & $\begin{array}{l}\text { Finance, Raw Materials, } \\
\text { Labour, Marketing }\end{array}$ & Rattan Industry \\
\hline 5 & Enterprise 5 & Jambi & $\begin{array}{l}\text { Finance, Raw Materials, } \\
\text { Labour, Marketing, Attractive } \\
\text { Packaging }\end{array}$ & Craft \\
\hline 6 & Enterprise 6 & South Sumatra & $\begin{array}{l}\text { Finance, Raw Materials, } \\
\text { Labour, Marketing, }\end{array}$ & Furniture \\
\hline 7 & Enterprise 7 & Bengkulu & Finance, Labour, Marketing & Freshwater Fishing \\
\hline 8 & Enterprise 8 & Lampung & $\begin{array}{l}\text { Finance, Raw Materials, } \\
\text { Labour, Marketing, Attractive } \\
\text { Packaging }\end{array}$ & Food Packaging \\
\hline 9 & Enterprise 9 & $\begin{array}{l}\text { Bangka Belitung } \\
\text { Islands }\end{array}$ & $\begin{array}{l}\text { Finance, Raw Materials, } \\
\text { Labour, Attractive Packaging }\end{array}$ & Culinary \\
\hline 10 & Enterprise 10 & Riau Islands & $\begin{array}{l}\text { Finance, Raw Materials, } \\
\text { Labour }\end{array}$ & Mini Market \\
\hline 11 & Enterprise 11 & DKI Jakarta & $\begin{array}{l}\text { Finance, Raw Materials, Mar- } \\
\text { keting }\end{array}$ & Culinary \\
\hline 12 & Enterprise 12 & West Java & $\begin{array}{l}\text { Finance, Raw Materials, } \\
\text { Labour, Marketing, Attractive } \\
\text { Packaging }\end{array}$ & Culinary \\
\hline 13 & Enterprise 13 & Central Java & $\begin{array}{l}\text { Finance, Raw Materials, } \\
\text { Labour, Marketing, Attractive } \\
\text { Packaging }\end{array}$ & Craft \\
\hline 14 & Enterprise 14 & In Yogyakarta & Finance, Marketing & Culinary \\
\hline 15 & Enterprise 15 & East Java & $\begin{array}{l}\text { Finance, Raw Materials, } \\
\text { Labour, Marketing, Attractive } \\
\text { Packaging }\end{array}$ & Food Packaging \\
\hline 16 & Enterprise 16 & Banten & $\begin{array}{l}\text { Raw Materials, Marketing, At- } \\
\text { tractive Packaging }\end{array}$ & Honey \\
\hline 17 & Enterprise 17 & Bali & $\begin{array}{l}\text { Finance, Raw Materials, } \\
\text { Labour, Marketing, Attractive } \\
\text { Packaging }\end{array}$ & Culinary \\
\hline 18 & Enterprise 18 & $\begin{array}{l}\text { West Nusa Teng- } \\
\text { gara }\end{array}$ & $\begin{array}{l}\text { Finance, Raw Materials, } \\
\text { Labour, Marketing, Attractive } \\
\text { Packaging }\end{array}$ & Printing \\
\hline 19 & Enterprise 19 & $\begin{array}{l}\text { East Nusa Teng- } \\
\text { gara }\end{array}$ & $\begin{array}{l}\text { Finance, Labour, Marketing, } \\
\text { Attractive Packaging }\end{array}$ & Craft \\
\hline 20 & Enterprise 20 & West Kalimantan & $\begin{array}{l}\text { Finance, Raw Materials, } \\
\text { Labour }\end{array}$ & Culinary \\
\hline 21 & Enterprise 21 & $\begin{array}{l}\text { Central Kaliman- } \\
\text { tan }\end{array}$ & $\begin{array}{l}\text { Finance, Raw Materials, } \\
\text { Labour }\end{array}$ & Culinary \\
\hline 22 & Enterprise 22 & $\begin{array}{l}\text { South Kaliman- } \\
\text { tan }\end{array}$ & $\begin{array}{l}\text { Finance, Raw Materials, } \\
\text { Labour, Marketing, Attractive } \\
\text { Packaging }\end{array}$ & Culinary \\
\hline 23 & Enterprise 23 & East Kalimantan & $\begin{array}{l}\text { Finance, Raw Materials, } \\
\text { Labour, Marketing, Attractive } \\
\text { Packaging }\end{array}$ & Culinary \\
\hline
\end{tabular}




\begin{tabular}{|c|c|c|c|c|}
\hline No & $\begin{array}{l}\text { Name of the } \\
\text { Firms }\end{array}$ & Province & $\begin{array}{l}\text { Constraints in Business During } \\
\text { Pandemic }\end{array}$ & Business Fields \\
\hline 24 & Enterprise 24 & $\begin{array}{l}\text { North Kaliman- } \\
\text { tan }\end{array}$ & $\begin{array}{l}\text { Finance, Raw Materials, } \\
\text { Labour, Marketing, Attractive } \\
\text { Packaging }\end{array}$ & Craft \\
\hline 25 & Enterprise 25 & North Sulawesi & $\begin{array}{l}\text { Finance, Raw Materials, } \\
\text { Labour, Marketing }\end{array}$ & Culinary \\
\hline 26 & Enterprise 26 & Central Sulawesi & Finance, Raw Materials & Culinary \\
\hline 27 & Enterprise 27 & South Sulawesi & $\begin{array}{l}\text { Finance, Raw Materials, } \\
\text { Labour, Marketing }\end{array}$ & Culinary \\
\hline 28 & Enterprise 28 & $\begin{array}{l}\text { Southeast Su- } \\
\text { lawesi }\end{array}$ & $\begin{array}{l}\text { Finance, Raw Materials, } \\
\text { Labour, Marketing, Attractive } \\
\text { Packaging }\end{array}$ & Culinary \\
\hline 29 & Enterprise 29 & Gorontalo & Finance, Marketing & Culinary \\
\hline 30 & Enterprise 30 & West Sulawesi & $\begin{array}{l}\text { Finance, Raw Materials, } \\
\text { Labour, Marketing, Attractive } \\
\text { Packaging }\end{array}$ & Culinary \\
\hline 31 & Enterprise 31 & Maluku & $\begin{array}{l}\text { Finance, Raw Materials, } \\
\text { Labour, Marketing, Attractive } \\
\text { Packaging }\end{array}$ & Craft \\
\hline 32 & Enterprise 32 & North Maluku & $\begin{array}{l}\text { Finance, Raw Materials, Mar- } \\
\text { keting, Attractive Packaging }\end{array}$ & $\begin{array}{l}\text { Traditional } \\
\text { medicine }\end{array}$ \\
\hline 33 & Enterprise 33 & West Papua & $\begin{array}{l}\text { Finance, Labour, Marketing, } \\
\text { Attractive Packaging }\end{array}$ & Craft \\
\hline 34 & Enterprise 34 & Papua & $\begin{array}{l}\text { Finance, Raw Materials, } \\
\text { Labour, Marketing, Attractive } \\
\text { Packaging }\end{array}$ & $\begin{array}{l}\text { Traditional } \\
\text { medicine }\end{array}$ \\
\hline
\end{tabular}

Source: Field interview, 2020

use manual production techniques or labor-intensive system where labor is an essential input in production. The fourth main challenge is marketing, constituting $21 \%$ of overall challenges. Marketing and advertising play even bigger role for MSMEs struggling to sell the products during the pandemic period where physical mobility is restricted. Finally, the last challenge for MSMEs is to make attractive packaging, constituting $15 \%$ of all challenges.

\section{Discussion and Conclusion}

MSMEs generally are challenged by the lack of entrepreneurial training by local governments, low demand for commodities, lack of business experience, skills and knowledge, limited access to financing, poor marketing skills, poor managerial skills, lack of planning skills, and poor core strategies development.

From the results of this study, using a descriptive qualitative approach from interview and literature study in Indonesia and the rest of the world, it can be concluded that the COVID-19 has a negative impact on MSMEs' businesses. Many MSMEs had to close down the business due to social restrictions imposed by the government, unsold merchandise resulting in declining revenues and increasing financial burden, decreasing working capital to purchase raw materials to run 


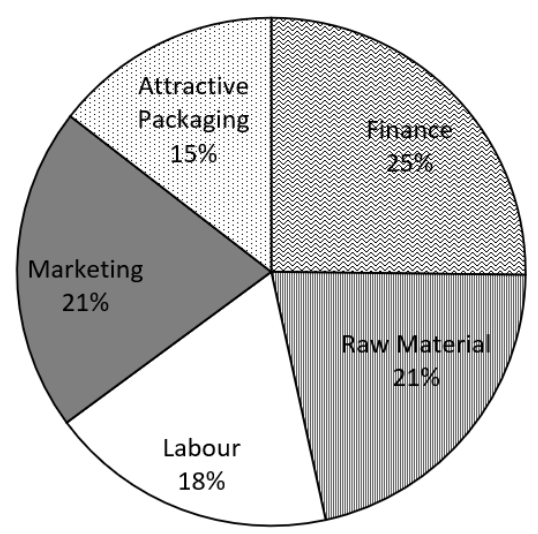

Figure 1: Share of MSMEs Business Constraints During Pandemic in Indonesia Source: Author's calculation

the production, and inability to adapt to new marketing techniques to overcome the changing business environment due to the pandemic. The mitigation of the impact of the COVID-19 pandemic on MSMEs' business can to be done in three ways. First, debriefing and education are essential. In this matter, representations of MSMEs communities from various provinces in Indonesia are given a briefing or education on sustainable business that can help MSMEs in dealing with the economic challenges. Considering the ongoing pandemic, it can use online media such as google meet or zoom applications which can save learning costs and avoid the spread of COVID-19 in accordance with government regulations. Second, specific production training and workshop is crucial. In this matter, the MSMEs communities are given training on creative economic products that can compete with other countries, including how to determine the products that are marketable in both domestic and international markets Third, MSMEs also require assistance in product marketing. At this stage, the MSMEs communities are assisted by the Ministry of Trade to determine which countries are export destinations, in point 3 the people do not sell their products not only for export consumption but can also be sold domestically.

This study would re-emphasize Goldberg et al. (2020) that suggests six main strategies to be emphasized by local MSME owners to manage the impact of the COVID-19 pandemic. They include monitoring customer behaviour frequently, managing the cash flow carefully, communicating intensively with suppliers, balancing the production and the demand, and considering a work from home policy for their employees.

In mitigating the impact of the pandemic, the government of Indonesia issued three regulations: (1) Government Regulation in Lieu of Law (Perppu) No. 1 of 2020 concerning State Financial Policy and Financial System Stability for Handling COVID-19 Pandemic and/or in the context of facing threats that en- 
danger the National Economy and/or Financial System Stability; (2) Government Regulation (PP) No. 21 of 2020 concerning Large-Scale Social Restrictions in the framework of the Acceleration of COVID-19 Handling; and (3) Presidential Decree (Kepres) Number 11 of 2020 concerning Determination of COVID-19 Public Health Emergency. Next studies in this area of research may examine the effectiveness of those regulations in mitigating the impact of the pandemic on MSMEs.

\section{References}

[1] ABDSI. (2020). Dampak COVID-19 terhadap bisnis UMKM. Association of Business Development Services Indonesia.

[2] Baldwin, R., \& di Mauro, B. W. (2020). Economics in the time of Covid-19. VOX CEPR Policy Portal. Available at https://voxeu.org/debates/economics-time-covid-19.

[3] Bick, D. (2020). COVID-19: 2020 is the International Year of the Midwife. Midwifery, 85, 102719. doi: 10.1016/j.midw.2020.102719.

[4] Bogdan, R. \& Biklen, S. K. (2007). Qualitative research for education: An introduction to theories and methods (5th edition). Pearson.

[5] Breaugh, J. (2020). Too Stressed To Be Engaged? The Role of Basic Needs Satisfaction in Understanding Work Stress and Public Sector Engagement. Public Personnel Management [First Published March 16, 2020]. doi: https://doi.org/10.1177/0091026020912516.

[6] Creswell, J. W. (2009). Research design: Qualitative, quantitative, and mixed methods approaches (4th edition). California: SAGE Publications.

[7] Danim, S. (2002). Menjadi peneliti kualitatif. Bandung: Pustaka Setia.

[8] Denzin, N. K., \& Lincoln, Y. S. (Eds.). (1994). Handbook of qualitative research. Sage Publications.

[9] Els, C., Grobbelaar, S., \& Kennon D. (2020). Complementary Partnerships for SMEs: A Relational Capability Maturity Model from an Ecosystem Perspective. In Hattingh M., Matthee M., Smuts H., Pappas I., Dwivedi Y., \& Mäntymäki M. (eds), I3E 2020: Responsible Design, Implementation and Use of Information and Communication Technology (pp. 67-78). Lecture Notes in Computer Science, vol 12066. Conference on e-Business, e-Services and e-Society. Springer, Cham. doi: https:/ /doi.org/10.1007/978-3-03044999-5\%6.

[10] Fernandes, N. (2020). Economic effects of coronavirus outbreak (COVID-19) on the world economy. Available at https://mediaroom.iese.edu/wp-content/uploads/2020/03/ Fernandes-Nuno_20200322-Global-Recession-is-inevitable.pdf.

[11] Goldberg, M. F., Goldberg, M. F., Cerejo, R., \& Tayal, A. H. (2020). Cerebrovascular Disease in COVID-19. American Journal of Neuroradiology [Published May 2020]. doi: https://doi.org/10.3174/ajnr.A6588.

[12] Grint, K. (2020). Leadership, management and command in the time of the coronavirus. Leadership [First Published April 23, 2020]. doi: https://doi.org/10.1177/1742715020922445.

[13] Gumbi, L., \& Twinomurinzi, H. (2020). SMME Readiness for Smart Manufacturing (4IR) Adoption: A Systematic Review. In M. Hattingh, M. Matthee, H. Smuts, I. Pappas, Y. Dwivedi, \& M. Mäntymäki (eds.), Conference on e-Business, e-Services and e-Society: I3E 2020: Responsible Design, Implementation and Use of Information 
and Communication Technology (pp. 41-54), Skukuza, South Africa, April 6-8, 2020, Springer, Cham.

[14] ILO. (2020). Laporan penelitian SCORE terhadap perusahaan Indonesia terdampak Covid19.

[15] Kanupriya. (2020). COVID-19: A Socio-economic Perspective. FIIB Business Review [First Published May 12, 2020]. doi: https://doi.org/10.1177/2319714520923918.

[16] Karnon, J. (2020). The case for a temporary COVID-19 income tax levy now, during the crisis. Applied Health Economics and Health Policy, 18, 335-337. doi: https://doi.org/10.1007/s40258-020-00585-6.

[17] Li, Q., Guan, X., Wu, P., Wang, X., Zhou, L., Tong, Y., ... \& Xing, X. (2020). Early transmission dynamics in Wuhan, China, of novel coronavirus-Infected pneumonia. The New England Journal of Medicine [Published March 26, 2020]. doi: 10.1056/NEJMoa2001316.

[18] Liu, Y., Lee, J. M., \& Lee, C. (2020). The challenges and opportunities of a global health crisis: the management and business implications of COVID-19 from an Asian perspective. Asian Business \& Management [Published online 12 May 2020]. doi: https://doi.org/10.1057/s41291-020-00119-x.

[19] Lu, X., Zhang, L., \& Du, H. (2020). SARS-CoV-2 Infection in Children. The New England Journal of Medicine, 382, 1663-1665. doi: 10.1056/NEJMc2005073.

[20] McCloskey, B., \& Heymann, D. L. (2020). SARS to novel coronavirus-old lessons and new lessons. Epidemiology $\mathcal{E}$ Infection, 148, E22. doi: https://doi.org/10.1017/S0950268820000254.

[21] Nelson, L. M., Simard, J. F., Oluyomi, A., Nava, V., Rosas, L. G., Bondy, M., \& Linos, E. (2020). US public concerns about the COVID-19 pandemic from results of a survey given via social media. JAMA Internal Medicine [Published online April 7, 2020]. doi: 10.1001/jamainternmed.2020.1369.

[22] Revindo, M. D. (2017). Internationalisation of Indonesian SMEs (Doctoral dissertation, Lincoln University). Available at http://researcharchive.lincoln.ac.nz/handle/ $10182 / 8608$.

[23] Revindo, M. D., Sabrina, S., \& Sowwam, M. (2020). Dampak pandemi COVID19 terhadap pariwisata Indonesia: Tantangan, outlook dan respon kebijakan. Briefing Note April 2020. LPEM FEB UI. Available at https://www.lpem.org/ briefing-note-april-2020-dampak-pandemi-covid-19-terhadap-pariwisata-indonesiatantangan-outlook-dan-respon-kebijakan/.

[24] SimpulRakyat.co.id. (2020, 01 April). Bappenas sarankan UMKM terdampak Covid19 perlu pendampingan. Available at https://www.simpulrakyat.co.id/2020/04/ bappenas-sarankan-umkm-terdampak-covid-19-perlu-pendampingan.html.

[25] Suryahadi, A., Al Izzati, R., \& Suryadarma, D. (2020). The impact of COVID-19 outbreak on poverty: An estimation for Indonesia. SMERU Working Paper [draft]. Available at https://www.smeru.or.id/en/content/ impact-covid-19-outbreak-poverty-estimation-indonesia.

[26] Van Tiem, D. M. \& Burns, N. C. (2020). Cases on performance improvement innovation. IGI Global

[27] Vranckx, P., Price, S., \& Christian Hassager, C. (2020). United we stand, divided we fall. European Heart Journal: Acute Cardiovascular Care [First Published May 6, 2020]. doi: https://doi.org/10.1177/2048872620923594.

[28] Wang, X., Weaver, N., \& Xue, N. (2019). Challenges for the Chinese economy in the new era of development. Journal of Chinese Economic and Business Studies, 17(1), 1-7. 
doi: https://doi.org/10.1080/14765284.2019.1582225.

[29] WHO. (2020). Coronavirus disease (COVID-19). World Health Organization. Available at https://www.who.int/indonesia/news/novel-coronavirus.

[30] Xu, C., Luo, X., Yu, C., \& Cao, S. J. (2020). The 2019-nCoV epidemic control strategies and future challenges of building healthy smart cities. Indoor and Built Environment, 29(5), 639-644. doi: https://doi.org/10.1177/1420326X20910408.

[31] Yu, K. D. S., \& Aviso, K. B. (2020). Modelling the economic impact and ripple effects of disease outbreaks. Process Integration and Optimization for Sustainability [Short Technical Note], 1-4. doi: https:/ /doi.org/10.1007/s41660-020-00113-y. 